Clark, J. B. \& Webb, R. B. (1954). J. gen. Microbiol. 11, 394-397.

\title{
Mitosis-like Figures in Corynebacterium pseudodiphtheriticum
}

\author{
By J. B. CLARK ANd R. B. WEBB \\ Department of Plant Sciences, University of Oklahoma, Norman, U.S.A.
}

SUMMARY : By combining nucleus and cell-wall studies on the same bacterial cells, it was demonstrated that many mitosis-like configurations are actually divided by cross-septa. The results do not signify the absence of classical mitotic figures, but they do show that a nuclear study by itself is not sufficient to establish the existence of such configurations in the bacterial cell.

It is now generally agreed that bacteria contain a discrete body that resembles the nucleus of the cells of higher forms of life in both chemical composition and general activity. The division of this nuclear body is orderly since there is a uniform distribution of genetic determinants to the daughter cells. However, whether this division occurs in bacteria by a mitotic mechanism similar to that found in other cells has not yet been proven. DeLamater (1951, 1952 a-c), DeLamater \& Mudd (1951), DeLamater \& Hunter (1951), and DeLamater \& Woodburn (1952) offered evidence as to the existence of true mitosis in several bacterial species. This work has been criticized by Bisset $(1950,1952 a, b, 1953 a, b, 1954)$ as a misinterpretation of cytological events. It has been shown that a study of nuclear activity in bacteria without consideration of events of cytokinesis may lead to spurious interpretations (Chance, 1953 a; Webb \& Clark, 1954; Webb, Clark \& Chance, 1954).

In the course of several cytological investigations on bacteria, nuclear configurations were sometimes observed which were strongly suggestive of various stages of a mitotic division. These mitosis-like figures were observed most frequently in Corynebacterium pseudodiphtheriticum. Since septation can easily be the basis of artefacts when a nuclear strain is used alone on bacterial cells (Bisset, 1954), a cell-wall study was used in conjunction with the study of nuclear figures.

\section{METHODS}

Nuclear studies were made by using a modification of the crystal violet stain (Chance, 1952). In this procedure a $0.5 \%$ mercuric chloride solution was used for $20 \mathrm{sec}$. as a mordant. Selected fields for study were recorded by a vernier mechanical stage and photographs made on Kodak panatomic-X film with a Gamma photomicrographic camera. The oil was removed from the slide with toluene and the slide was then decolorized by soaking overnight in $50 \%(\mathrm{v} / \mathrm{v})$ ethanol in water before restaining to show cell walls. The cell-wall stain was a modification of the tannic acid-violet method (Webb, 1954). The microscopic fields studied for nuclear activity were again located and photographed. This gave both a nuclear and cell-wall study of the same cells. A similar procedure was used by Robinow (1945). 


\section{RESULTS AND DISCUSSION}

A study of nuclear appearance and activity, per se, is not sufficient to prove the existence of true mitosis in bacteria. The minute details of the nuclear configurations are too near the limits of the resolution of the microscope to allow critical study of them alone. Also, small staining irregularities or artefacts could be interpreted with false significance. Bisset (1950) and other workers have pointed out the complex cellularity of bacteria, and have referred to them as multicellular organisms. This complex cellularity has been found in many bacteria in that the normally recognized morphological unit may not be a single cell, but instead may be divided by cross-septa. The presence of these septa is not seen by normal nuclear studies, and what appears to be, for example, the chromosomal masses of an anaphase may really be two nuclear masses separated by mature cross-septa.

As shown in Pl. 1, figs. 1-19, many nuclear configurations which could easily be interpreted as various mitotic figures are actually nuclear bodies in separate cells of the 'multicellular' organism.

Chance $(1953 a, b)$ has demonstrated the formation of cell plates in several genera of bacteria, and the cell-plate configuration may in many cases appear similar to a metaphase. In larger cells in which cell plates are formed, it is obvious that this formation could not take place before the anaphase and in most cases it has been found to occur during the telophase. The plate formation is the initiation of septum formation, and it has been found that the actual septum is not formed in bacteria until late in the development of the plate (unpublished data). Therefore, it can only be concluded that these mitosis-like configurations do not conform to the classical mitotic figures.

Similar configurations have been observed in other micro-organisms, but much less frequently than in Corynebacterium pseudodiphtheriticum. Since this project was intended primarily to explore the possibility of cross-septation leading to false interpretations, the study was concentrated on this one organism. It must be considered that the exact staining mechanism of the crystal violet nuclear stain is unknown. Intensive cytological studies have shown this procedure to be specific for bodies that display nuclear activity. However, preliminary work in our laboratory has indicated that the specificity of the stain is for protein components of the nucleus rather than for deoxyribonucleic acid. Thus this stain procedure is not directly comparable with the techniques routinely used in other laboratories. The general conclusions obtained by use of the crystal violet stain, however, should apply to bacterial cytology in general.

These results do not signify that classical mitotic figures do not occur in bacteria, but they do show that a nuclear study by itself is insufficient to establish their existence. It is possible that mitosis in bacteria occurs by some different, as yet unrecognized pathway. Perhaps in bacterial mitosis the timing of events of cytokinesis in relation to karyokinesis is different from that in other cells, and the cross-septum forms early in nuclear division. Such matters are still open to speculation on the basis of present information. 
However, it is clear that there is little justification for claiming the existence of a true mitotic cycle in bacteria on the sole basis that some cells are seen to contain a nuclear mass which resembles a mitotic configuration.

This investigation was supported in part by the Medical Research and Development Board, Office of the Surgeon General, Department of the Army, under contract No. DA-49-007-MD-319. Presented before 53rd Annual Meeting of Society of American Bacteriologists, San Francisco, California, 10-14 August 1953.

\section{REFERENCES}

Bisset, K. A. (1950). Cytology and Life history of bacteria. Baltimore, Maryland: The Williams and Wilkins Co.

Bisset, K. A. (1952a). Spurious mitotic spindles and fusion tubes in bacteria. Nature, Lond. 169, 247.

Bisset, K. A. (1952b). The interpretation of appearances in the cytological staining of bacteria. Exp. Cell Res. 3, 681.

Bisset, K. A. $(1953 a)$. Criticism of a technic claimed to demonstrate mitotic spindles in bacteria. Stain Tech. 28, 45 .

Bisset, K. A. (1953). Do bacteria have mitotic spindles, fusion tubes and mitochondria? J. gen. Microbiol. 8, 50.

Bisset, K. A. (1954). The cytology of Micrococcus cryophilus. J. Bact. 67, 41.

Chance, H. L. (1952). Crystal violet as a nuclear stain for Gaffkya tetragena and other bacteria. Stain Tech. 27, 253.

Chance, H. L. (1953a). Cytokinesis in Gaffkya tetragena. J. Bact. 65, 593.

Chance, H. L. (1953b). The occurrence of 'cell plates' in bacteria. J. Bact. 66, 239.

DeLamater, E. D. (1951). Evidence for the occurrence of true mitosis in bacteria. Science, 113, 477.

DeLamater, E. D. (1952a). Preliminary observations on the occurrence of a typical mitotic process in micrococci. Bull. Torrey Bot. Cl. 79, 1.

DeLamater, E. D. (1952b). A new cytological basis for bacterial genetics. Cold Spr. Harb. Symp. quant. Biol. 16, 381.

Delamater, E. D. (1952 $c$ ). Preliminary observations on the occurrence of mitosis in Caryophanon latum. Mycologia, 44, 203.

Delanater, E. D. \& Hunter, M. E. (1951). Preliminary report of true mitosis in vegetative cell of Bacillus megatherium. Amer. J. Bot. 38, 659 .

Delamater, E. D. \& Mudd, S. (1951). The occurrence of mitosis in the vegetative phase of Bacillus megatherium. Exp. Cell Res. 2, 499.

Delamater, E. D. \& Woodburn, M. (1952). Evidence for the occurrence of mitosis in the micrococci. J. Bact. 64, 793.

Rosinow, C. F. (1945). Addendum to Dubos, The Bacterial Cell, Cambridge, Mass.: Harvard University Press.

WEBB, R. B. (1954). A bacterial cell wall stain. J. Bact. 67, 252.

WEBB, R. B. \& ClARK, J. B. (1954). Cell division in Micrococcus pyogenes var. aureus. J. Bact. 67, 94.

Webb, R. B., Crark, J. B. \& Chance, H. L. (1954). A cytological study of Nocardia corallina and other actinomycetes. J. Bact. 67, 498. 

Journal of General Microbiology, Vol. 11, No. 3
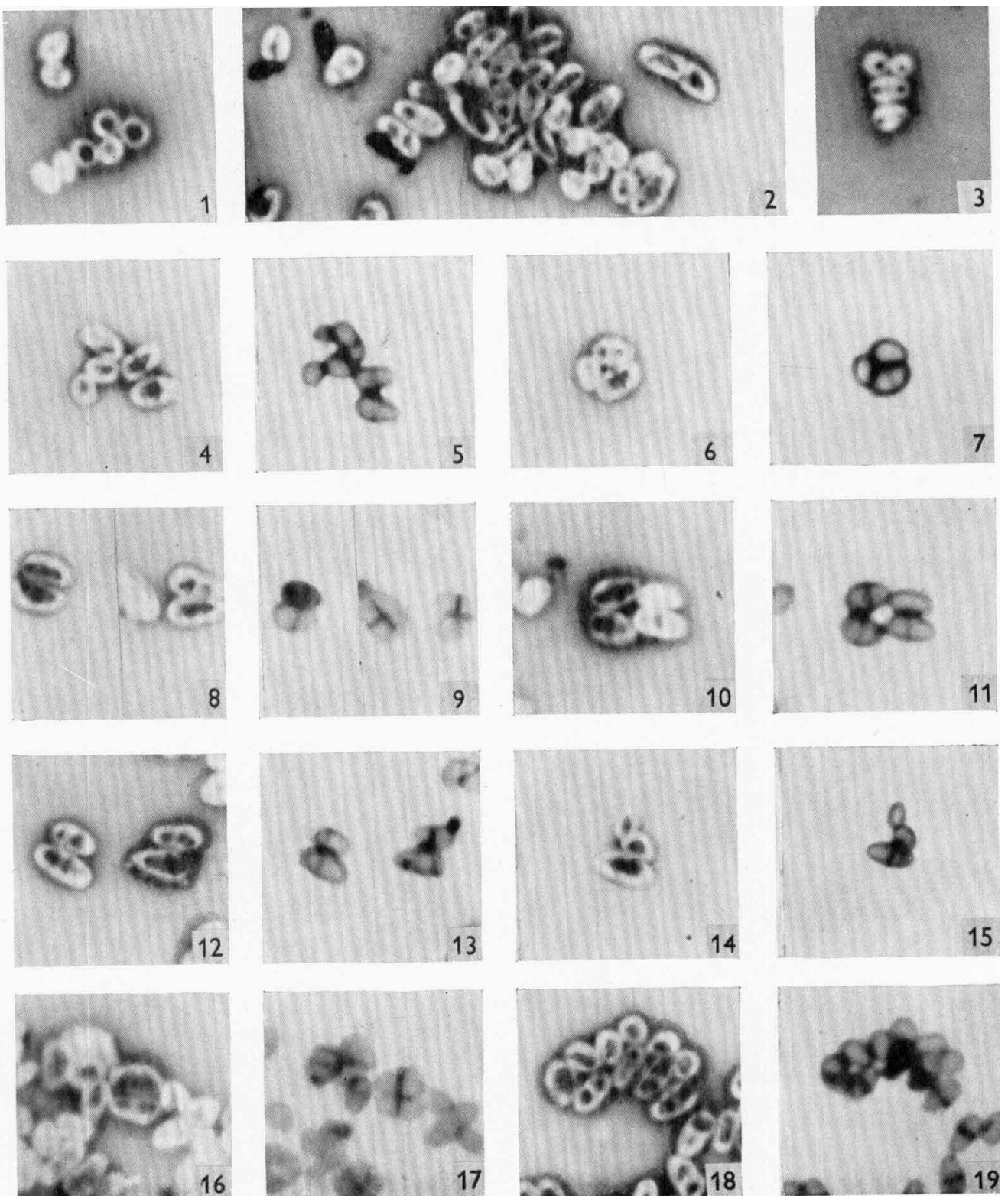

J. B. Clark \& R. B. Webb-Mitosis-like figures in Bacteria 


\section{EXPLANATION OF PLATE}

Mitosis-like figures in Corynebacterium pseudodiphtheriticum (All photographs $\times 3200$ ). Figs. 1-3. Variation in nuclear appearance in Corynebacterium pseudodiphtheriticum.

Figs. 4 and 6. Cell-plate formation.

Figs. 5 and 7 . Cell-wall stains of cells shown in Figs. 4 and 6.

Fig. 8. Anaphase and metaphase configurations.

Fig. 9. Cell wall stain of organisms shown in Fig. 8.

Fig. 10. Metaphase configuration.

Fig. 11. Cell wall stain of organisms shown in Fig. 10.

Figs. 12 and 14. Anaphase configurations.

Figs. 13 and 15. Cell wall stain of cells shown in Figs. 12 and 14.

Figs. 16 and 18. Late anaphase or early telophase configurations.

Figs. 17 and 19. Cell wall stain of cells shown in Figs. 16 and 18.

(Received 27 April 1954) 